\title{
Modern Trends in \\ Hypercomplex Analysis
}

Swanhild Bernstein • Uwe Kähler • Irene Sabadini Franciscus Sommen Editors 


\section{Editors}

Swanhild Bernstein

Institute of Applied Analysis

TU Bergakademie Freiberg

Freiberg, Germany

Irene Sabadini

Dipartimento di Matematica

Politecnico di Milano

Milano, Italy

\author{
Uwe Kähler \\ Departamento de Matemática \\ Universidade de Aveiro \\ Aveiro, Portugal \\ Franciscus Sommen \\ Department of Mathematical Analysis \\ Ghent University \\ Gent, Belgium
}

This work is published under the auspices of the International Society of Analysis, its Applications and Computation (ISAAC)

ISSN 2297-0215

Trends in Mathematics

ISBN 978-3-319-42528-3

DOI 10.1007/978-3-319-42529-0

Library of Congress Control Number: 2016959577
ISSN 2297-024X (electronic)

ISBN 978-3-319-42529-0 (eBook)

Mathematics Subject Classification (2010): 30G35, 30G25, 22E46, 32A50, 68U10

(C) Springer International Publishing Switzerland 2016

This work is subject to copyright. All rights are reserved by the Publisher, whether the whole or part of the material is concerned, specifically the rights of translation, reprinting, reuse of illustrations, recitation, broadcasting, reproduction on microfilms or in any other physical way, and transmission or information storage and retrieval, electronic adaptation, computer software, or by similar or dissimilar methodology now known or hereafter developed.

The use of general descriptive names, registered names, trademarks, service marks, etc. in this publication does not imply, even in the absence of a specific statement, that such names are exempt from the relevant protective laws and regulations and therefore free for general use.

The publisher, the authors and the editors are safe to assume that the advice and information in this book are believed to be true and accurate at the date of publication. Neither the publisher nor the authors or the editors give a warranty, express or implied, with respect to the material contained herein or for any errors or omissions that may have been made.

Printed on acid-free paper

This book is published under the trade name Birkhäuser, www.birkhauser-science.com

The registered company is Springer International Publishing AG

The registered company address is: Gewerbestrasse 11, 6330 Cham, Switzerland 